\title{
Utilization of Learning Videos Based on Japanese Occupation Materials in Indonesia as Digital History Learning Objects
}

\author{
Muhammad Dwi Kurniadi, Rizki Ananda Hsb, Zulkarnain
}

Universitas Negeri Yogyakarta

muhammad0077.pasca2019@student.uny.ac.id

\section{Article History}

accepted 1/09/2020

approved 4/10/2020

published $1 / 12 / 2020$

\begin{abstract}
This research aims to analyze the benefits of Japanese Occupation Material-based Learning Video in Indonesia as a Digital History Learning Object whose problem formulations include :(1) How can Japanese Occupation Materials in Indonesia become objects of historical learning? (2) How can the use of material-based historical learning videos in Indonesia become objects of digital history learning? To answer both problems, the authors used a qualitative approach with a literary study method that collected several articles from previous research results as well as related to research themes. From the results of the research obtained that japanese occupation materials in Indonesia can be used as objects of historical learning because it corresponds to the needs of core competencies and basic competencies of history learning in high school, as well as to improve the nationalist attitude of students, by herding students to imagine the material of occupation in Indonesia through learning videos so that students can see the events of japanese occupation in Indonesia directly. Then based on previous research also explained that the results of the study using video learning based on japanese occupation materials in Indonesia is in effective value to be used as a medium of historical learning.
\end{abstract}

Keywords : Learning videos, Japanese occupation, historical learning

\begin{abstract}
Abstrak
Penelitian ini bertujuan untuk menganalisis manfaat Video Pembelajaran berbasis Materi Pendudukan Jepang di Indonesia Sebagai Objek Pembelajaran Sejarah Digital yang rumusan masalahnya meliputi :(1) Bagaimana Materi Pendudukan Jepang di Indonesia dapat menjadi objek pembelajaran sejarah? (2) Bagaimana pemanfaatan video pembelajaran sejarah berbasis materi Pendudukan Jepang di Indonesia dapat menjadi objek pembelajaran sejarah digital ? Untuk menjawab kedua permasalahan tersebut, penulis menggunakan pendekatan kualitatif dengan metode studi literatur yang mengumpulkan beberapa artikel dari hasil penelitian terdahulu serta berkaitan dengan tema penelitian. Dari hasil penelitian di peroleh bahwa materi pendudukan Jepang di Indonesia dapat dijadikan objek pembelajaran sejarah karena sesuai dengan kebutuhan kompetensi inti dan kompetensi dasar pembelajaran sejarah di SMA, serta untuk meningkatkan sikap nasionalis peserta didik, dengan menggiring siswa untuk mengimajinasikan materi pendudukan di Indonesia melalui video pembelajaran sehingga siswa dapat melihat peristiwa pendudukan jepang di Indonesia secara langsung. Kemudian berdasarkan penelitian terdahulu turut menjelaskan bahwa hasil penelitian yang menggunakan video pembelajaran berbasis materi pendudukan jepang di Indonesia ini di nilai efektif untuk dijadikan media pembelajaran sejarah.
\end{abstract}

Kata Kunci : Video pembelajaran, pendudukan Jepang, pembelajaran sejarah

Social, Humanities, and Education Studies (SHEs): Conference Series https://jurnal.uns.ac.id/shes

p-ISSN 2620-9284

e-ISSN 2620-9292

This work is licensed under a Creative Commons Attribution-ShareAlike 4.0 International License. 


\section{PENDAHULUAN}

Pembelajaran dapat berkaitan dengan berbagai bidang keilmuan salah satu bentuk bidang keilmuan tersebut adalah sejarah. Seperti yang disampaikan Susanto (2014: 29) pembelajaran sejarah adalah upaya pembentukan karakter dengan upaya memberi pemahaman dan kembali meneguhkan nilai-nilai perjuangan dalam perjalanan sebuah bangsa. Mempelajari sejarah berarti membangkitkan kembali nilai-nilai masa lalu yang akan mempengaruhi bagaimana kita memandang dunia pada masa sekarang dan untuk masa depan.

Pembelajaran sejarah mengandung seperangkat bagian yaitu tujuan, materi, subyek belajar (peserta didik), guru, metode dan teknik, media serta penilaian. Semua bagian tersebut berinteraksi satu sama lain untuk mencapai tujuan yang telah ditetapkan. Peran guru dalam mencapai keberhasilan pembelajaran sejarah berhubungan erat dengan tiga komponen yang saling bergantung dan saling mengisi: materi-metode-media pembelajaran. Keterbatasan wawasan dan referensi guru sejarah merupakan kendala bagi pelaksanaan pembelajaran sejarah yang komprehensif dan mantap. (Abdullah, dkk. Tanpa tahun: 25).

Sejalan dengan pendapat diatas Suwarni (2016: 126-128) mengatakan bahwa lewat sejarah para peserta didik akan belajar memahami bermacam kenyataan hidup masyarakat dengan berbagai masalah, dan cara pemecahannya tidak mungkin dilakukan dengan kerangka kerja disiplin keilmuan secara terpisah. Jadi, dapat disimpulkan bahwa dalam proses pembelajarannya, mata perlajaran sejarah tidak bertujuan untuk memenuhi ingatan para peserta didik dengan bermcama-macam fakta dan materi yang harus dihafal, akan tetapi untuk membina mental yang sadar akan tanggung jawab terhadap hak dirinya sendiri dan kewajiban kepada masyarakat luas.

Menurut kurikulum 2013 SMA pada materi pendudukan jepang di Indonesia disebutkan kompetensi dasar yang harus dikuasai oleh peserta didik adalah seperti bisa menganalisis sifat pendudukan jepang dan respon bangsa Indonesia, kemudian mampu menalar sifat pendudukan dan respon bangsa Indonesia dan menyajikannya dalam bentuk cerita sejarah, sehubung dengan hal itu materi pendudukan jepang yang dipelajari oleh peserta didik tingkat SMA ini di bagi lagi menjadi 3 sub bab dengan pokok bahasan pertama kedatangan jepang ke Indonesia, kedua penjajahan jepang di Indonesia, ketiga tujuan pendudukan jepang.

Dengan meninjau dari penjelasan Kurikulum 2013 yang memiliki tujuan agar peserta didik mampu menganalisis sifat pendudukan jepang dan respon bangsa Indonesia, kemudian mampu menalar sifat pendudukan dan respon bangsa Indonesia dan menyajikannya dalam bentuk sejarah agar hal itu dapat dicapai secara maksimal maka diperlukannya sebuah usaha penyampaian materi pembelajaran dalam bentuk media pembelajaran berupa video pembelajaran, dapat ditarik pemahaman disini bahwa media adalah sesuatu yang berisikan pesan atau informasi yang disajikan dalam bentuk

tertentu dengan menggunakan peralatan. Dan media yang baik adalah media yang dapat membantu proses pembelajaran. Tentu saja manusia terlibat di dalam prosesnya.

Dilanjutkan pendapat menurut Sutirman (2013: 15) Media pembelajaran dapat dikatakan sebagai alat-alat grafis photografis atau elektronis yang dapat digunakan untuk menangkap, memproses, dan menyusun kembali informasi visual atau verbal.

Media merupakan komponen sumber belajar atau wahana fisik yang mengandung

materi instruksional di lingkungan peserta didik yang dapat merangsang peserta didik untuk belajar.

Namun dengan demikian proses pembelajaran tetap menjumpai beberapa masalah yang ada seperti keterbatasan guru dalam menggunakan media, dengan berkembangnya zaman maka diperlukan pula media pembelajaran yang inovatif, bertujuan untuk mengatasi masalah yang ada dalam proses pembelajaran seperti kurangnya minat peserta didik di dalam belajar, media pembelajaran yang kurang 
menarik dan membosankan serta cara tenaga pendidik dalam menyampaikan materi masih bersifat konvensional. Berdasarkan masalah yang dikemukakan di atas, maka dalam tulisan ini akan membahas Bagaimana Materi Pendudukan Jepang di Indonesia dapat menjadi objek pembelajaran sejarah dan Bagaimana pemanfaatan video pembelajaran sejarah berbasis materi Pendudukan Jepang di Indonesia dapat menjadi objek pembelajaran sejarah digital, dilakukan dengan seabik-baiknya semoga tulisan ini berguna sebagai sumbangan di bidang ilmu pengetahuan.

\section{METODE}

Metode yang digunakan dalam penulisan artikel ini ialah studi literatur. Metode kepustakaan ini (literature study) dikenal dengan metode pengumpulan data berlandaskan buku-buku, artikel ilmiah, jurnal, serta sumber tertulis yang memiliki relevansi dengan permasalahan yang dikaji. Peneliti menganalisis data yang diperoleh melalui strategi analisis data kualitatif deskriptif (Sugiyono, 2014:114). Kemudian John Creswell (2016:4) turut mengatakan bahwa penelitian kualitatif deskriptif ialah cara untuk mengesplorasi dan menungkap makna yang dianggap berasal dari masalah-masalah sosial. Dengan memanfaatkan dokumentasi untuk mengumpulkan informasi yang relevan dan berkaitan dengan masalah yang akan diteliti.

Sejalan dengan pernyataan di atas, Zed (2014) menuturkan bahwa pada riset pustaka, penelusuran pustaka tidak hanya untuk langkah awal mempersiapkan kerangka penelitian, akan tetapi sekaligus memanfaatkan sumber-sumber pustaka untuk memperoleh data penelitian. Review literatur ini bertujuan untuk membangun dan mengonstruksi konsepsi secara lebih kuat berbasis penelitian-penelitiam empiris yang relevan dan pernah dilakukan. Dalam studi ini peneliti memetakan buku-buku, hasil penelitian yang dimuat dalam artikel maupun skripsi yang kajiannya berkaitan dengan Pemanfaatan Video Pembelajaran Berbasis Materi Pendudukan Jepang di Indonesia Sebagai Objek Pembelajaran Sejarah Digital.

Adapun tahapan-tahapan yang dilakukan oleh peneliti mengikuti pendapat Bungin (2010:264) sebagai berikut: (1) mengumpulkan data awal seperti buku, artikel ilmiah, jurnal, dan sumber tertulis lainnya yang relevan dengan tema kajian, (2) mengolah data dengan menguraikan secara singkat korelasi antar kategori yang dianalisis melalui reduksi data, (3) menarik kesimpulan awal yang bersifat sementara dan dapat berubah jika ditemukan kembali fakta-fakta yang kuat pada pengumpulan data, (4) menguji keabsahan hasil penelitian dengan triangulasi sumber data, dan (5) penarikan kesimpulan hasil penelitian.

\section{HASIL DAN PEMBAHASAN}

\section{A. Materi Pendudukan Jepang menjadi Objek Pembelajaran Sejarah Digital}

Sejarah Indonesia merupakan studi atau kajian mengenai kemegahan/keunggulan dan nilai-nilai kejuangan bangsa Indonesia untuk ditransformasikan kepada generasi muda sehingga melahirkan generasi bangsa yang unggul dan penuh kearifan. Melalui materi sejarah peserta didik dapat mengenal jati dirinya dan nilai-nilai bangsa yang diperjuangkan pada masa lalu, yang dipertahankan dan disesuaikan untuk kehidupan masa kini dan dikembangkan dikehidupan saat ini dan akan datang. Nilai-nilai bangsa akan terlihat dalam nilai-nilai perjuangan, keberhasilan, dan keunggulan, semangat yang tidak pernah padam untuk memperjuangkan suatu kebenaran yang dilakukan para pelaku sejarah di masa lalu (Hasan, 2012:8).

Pembelajaran sejarah sebagai salah satu pembelajaran yang berkaitan dengan pengembangan serta pembinaan sikap kebangsaan, semangat nasionalisme, cinta tanah air, berjiwa demokrasi dan patriotisme. Peserta didik dalam pembelajaran sejarah di sekolahan idealnya dengan melihat secara langsung kehidupan nyata, bukan materi 
yang jauh dari realitas (Mulyono,2008:1). Salah satu hal yang mendekatkan materi tersebut adalah dengan memvisualisasikan materi dengan memanfaatkan video pembelajaran.

Berdasarkan hasil observasi kepada peserta didik, minat belajar peserta didik terhadap pelajaran sejarah masih sangat rendah. Rendahnya minat belajar tersebut di lihat dari kurangnya perhatian peserta didik terhadap guru yang sedang menjelaskan materi sejarah di kelas, peserta didik cenderung mengantuk saat pelajaran sejarah berlangsung dan kesibukan lainnya. Sedangkan dalam proses pembelajaran khususnya pembelajaran sejarah, minat belajar peserta didik sangat diperlukan,karena dari minat belajar akan mempengaruhi hasil belajar.

Penggunaan media pembelajaran yang bervariasi dalam proses belajar mengajar dapat membangkitkan minat belajar peserta didik dan tentunya membantu keefektifan penyampaian materi serta proses pembelajaran. Sebuah hasil penelitian Encyclopedia of Educational Research mengatakan bahwa pembelajaran dengan media dapat memberikan nilai atau manfaat diantaranya mengurangi verbalisme, kemudian menarik perhatian dan minat peserta didik, mendorong peserta didik untuk berani bertanya, serta materi yang didapatkan akan lebih menetap dan tidak mudah dilupakan (Usman, 1995:31).

Dari hasil observasi yang dilakukan terhadap peserta didik, dalam pembelajaran sejarah materi pendudukan Jepang di Indonesia merupakan salah satu materi yang sulit. Hal ini berdasarkan banyaknya peserta didik yang tidak memenuhi KKM dibandingkan dengan materi sejarah yang lain. Materi pendudukan Jepang di Indonesia menduduki tingkat kesulitan yang lebih tinggi. Kompetensi inti pada materi ini yaitu memahami, menerapkan, menganalisis pengetahuan factual, konseptual, procedural dan metakognitif berdasarkan rasa ingin tahu tentang ilmu pengetahuan.

Dibandingkan dengan materi sejarah yang lain, materi pendudukan Jepang di Indonesia menduduki tingkat kesulitan yang lebih tinggi karena sangat sedikit peserta didik yang tuntas pada materi ini. Kompetensi inti pada materi pendudukan Jepang yaitu memahami, menerapkan, menganalisis pengetahuan faktual, konseptual, prosedural dan metakognitif berdasarkan rasa ingin tahu tentang ilmu pengetahuan. Kompetensi inti selanjutnya yaitu mengolah, menalar, dan menyajikan dalam ranah kongkret dan ranah abstrak terkait dengan pengembangan dari yang dipelajari di sekolah secara mandiri. Selain kompetensi inti terdapat juga kompetensi dasar yang harus dicapai oleh peserta didik yaitu menganalisis sifat pendudukan Jepang dan respon bangsa Indonesia, dengan beberapa indikator yaitu menganalisis kedatangan Jepang ke Indonesia, menganalisis sifat pendudukan Jepang di Indonesia, dan menganalisis respon bangsa Indonesia terhadap pendudukan Jepang. Kompetensi dasar selanjutnya yaitu menalar sifat pendudukan Jepang dan respon bangsa Indonesia.

Materi pendudukan Jepang di Indonesia memiliki kajian yang cukup luas, mulai dari mengkaji latar belakang kedatangan jepang, sifat pendudukan Jepang, serta respon bangsa Indonesia terhadap pendudukan Jepang. Sebagian besar materi tersebut hanya disajikan dengan menggunakan buku paket dengan metode ceramah. Hal ini mengakibatkan peserta didik merasa kesulitan untuk memahami dengan baik materi yang disampaikan, karena mereka tidak memiliki gambaran yang jelas tentang materi pendudukan Jepang. Selain itu metode ceramah yang diterapkan oleh guru juga terkesan membosankan sehingga banyak peserta didik yang mengantuk dan tidak memperhatikan apa yang dijelaskan oleh gurunya. Karena dari segi substansi materi, bahan ajar yang digunakan oleh guru saat mengajar membutuhkan media yang dapat memperjelas apa yang disampaikan oleh guru, sehingga siswa dapat memahami dengan baik materi yang sedang diajarkan.

Media video di desain untuk menarik minat siswa dalam belajar, selain itu juga untuk memudahkan siswa memahami latar belakang pendudukan jepang di Indonesia karena didalam video terdapat peta kedatangan Jepang ke Indonesa dan juga terdapat 
gambaran bagaimana kekejaman jepang terhadap bangsa Indonesia yang tertuang pada cuplikan video romusha. Selain itu juga video di desain dengan menggunakan animasi yang unik dan terdapat narasi serta soundtrack musik, sehingga siswa tidak bosan saat menyaksikan video. Sedangkan media audio berfungsi untuk memfasilitasi siswa dengan gaya belajar yang lebih suka mendengar, bernyanyi, selain itu media audio ini dapat membantu penguatan materi, karena didalam media audio (lagu) yang dikembangkan ini terdapat lirik tentang materi pendudukan Jepang. Sehinga peserta didik akan lebih tertarik belajar sambil bernyayi, serta peserta didik juga lebih mudah mengingat dan memahami dengan jelas materi pendudukan Jepang di Indonesia.

\section{B. Pemanfaatan Video Pembelajaran Sejarah Digital}

Pembelajaran pastinya membutuhkan sautu media yang interaktif, dan tidak menutup kemungkinan bahwa pelajaran sejarah juga membutuhkannya. Karena pelajaran sejarah seringkali dianggap sebagai pelajaran yang membosankan. Dilanjutkan (Syahputra dkk, 2020: 83) yang berpendapat bahwa Penggunaan media dapat memperjelas pesan menjadi suatu yang nyata, tidak berbasis teks dan buku, memangkas ruang, waktu, tenaga, dan biaya. Jadi, Berkembangnya teknologi membawa perubahan terhadap segala bidang termasuk pendidikan. Dibutuhkan kreativitas tenaga pengajar dalam merenapkan pembelajaran sejarah yang menarik. Pada era Pendidikan 4.0 ini pembelajaran sejarah dituntut untuk mengombinasikan apa yang ada di masa lalu dengan perkembangan teknologi masa sekarang. Sebagai contoh pemanfaatan video pembelajaran sebagai objek pembelajaran sejarah digital.

Selain itu perlu juga diketahui bahwa dalam memilih sebuah sumber belajar harus juga mempertimbangkan apakah sumber belajar itu sesui dengan beberapa aspek seperti kriteria, fleksibel, dan sesuai dengan tujuan dan juga lingkungan dapat menjadi salah satu sumber belajar yang cukup penting karena memiliki nilai-nilai yang berharga untuk menambah pengetahuan sejarah peserta didik yang dimana diartikan lingkungan disini berarti lingkungan sosial dan lingkungan sosial, dan dengan membawa siswa kelapangan memberikan contoh nyata sumber belajar sejarah seperti karyawisata, praktik lapangan, tenaga pendidik akan menimbulkan sebuah minat belajar kepada siswa. Tenaga pendidik bisa memperkenalkan sebuah situs sejarah dengan memanfaatkan media seperti video, internet, e-book, dan web juga bisa memberikan sebuah pengalaman yang menarik kepada peserta didik.

Beberapa sumber belajar yang yang disebutkan diatas bisa dimanfaatkan dalam pembelajaran sejarah secara tersusun dengan baik dan saling berkaitan dengan sumber belajar sejarah berbasis materi pendudukan jepang di Indonesia,yang disebutkan pada kompetensi dasar yang harus dikuasai oleh peserta didik adalah seperti bisa menganalisis sifat pendudukan jepang dan respon bangsa Indonesia, kemudian mampu menalar sifat pendudukan dan respon bangsa Indonesia dan menyajikannya dalam bentuk cerita sejarah, sehubung dengan hal itu materi pendudukan jepang yang dipelajari oleh peserta didik tingkat SMA ini di bagi lagi menjadi 3 sub bab dengan pokok bahasan pertama kedatangan jepang ke Indonesia, kedua penjajahan jepang di Indonesia, ketiga tujuan pendudukan jepang.

Beberapa penelitian yang sudah dilakukan terkait dengan video pembelajaran telah dilaksanakan terbukti efektif sebagai objek pembelajaran sejarah digital dan dalam dunia pendidikan telah banyak penelitian tentang pengembangan baik berupa bahan ajar maupun media pemblajaran yang telah mendukung dan meningkatkan proses hingga hasil belajar menjadi lebih baik. Seperti yang sudah dijelaskan pada skripsi kurniadi ditahun 2018) berpendapat bahwa video pembelajaran dinyatakan layak dan efektif digunakan sebagai salah satu media pembelajaran di Sekolah Menengah Atas pada materi pendudukan Jepang di Indonesia serta dapat digunakan sebagai alternatif media pembelajaran mandiri siswa. 
Dilanjutkan lagi dari hasil penelitian Hafizh (2019: 224) dengan judul Pengembangan Media Pembelajaran Berbasis Video Menggunakan Windows Movie Maker Dalam Pembelajaran Sejarah mendapat kesimpulan setelah melakukan penilain uji validitas dari ahli media pembelajaran sejarah berbasis movie maker merupakan sumber belajar yang layak digunakan dan hal itu juga di dukung dari hasil validitas ahli materi, setelah di lakukan uji coba mendapatkan hasil sangat praktis untuk digunakan dalam pembelajaran sejarah menjadi efektif. Jika dikaitkan dengan pembelajaran sejarah digital tentu saja tidak menagcu kepada sebuah media pembelajaran yang terhubung ke media seperti video namun bisa juga berupa aplikasi dan penelitian yang dilakukan Khairurizqi (2015:178) dalam penelitiannya merancang aplikasi yang membahas tentang artefak dengan menggunakan sistem dari Gawai/Android. Konten yang terdapat dalam aplikasi adalah informasi tentang candi, informasi tentang artefak serta sejarah candi yang menjadikan pembelajaran menjadi lebih efektif karena menjadikan Artefak menjadi objek pembelajaran sejarah digital.

Dari penelitian yang ada diatas menjadikan hal ini jelas bahwa peserta didik lebih senang dengan media pembelajaran sejarah yang memanfaatkan teknologi yang bisa dipergunakan melalui gawai/telfon gengam atau media penampil lainnya. Dari beberapa penelitian dengan pendapat ahli pada paparan diatas, kita dapat memanfaatkan apapun yang nilainya dapat diimplementasikan pada kehidupan bermasyarakat. Terutam nilainilai yang dipetik dalam materi pembelajaran sejarah yang bisa menimbulkan sikap nasionalisme, gotong royong, dan kritis terhadap sejarah dan video bisa sebagai media penghantar antara para peserta didik dan guru untuk berdiskusi lebih mendalam lagi.

\section{SIMPULAN}

Sejarah sebagai sebuah bidang ilmu dan pembelajaran sejarah upaya pembentukan karakter dengan upaya memberi pemahaman dan kembali meneguhkan nilai-nilai perjuangan dalam perjalanan sebuah bangsa. Mempelajari sejarah berarti membangkitkan kembali nilai-nilai masa lalu yang akan mempengaruhi bagaimana kita memandang dunia pada masa sekarang dan untuk masa depan. Media merupakan komponen sumber belajar atau wahana fisik yang mengandung materi instruksional di lingkungan peserta didik yang dapat merangsang peserta didik untuk belajar.

Pemanfaatan Video Pembelajaran Berbasis Materi Pendudukan Jepang di Indonesia Sebagai Objek Pembelajaran Sejarah Digital memiliki posisi tersendiri di dalam pembelajaran sejarah, karena peserta didik akan merasakan pengalaman belajar yang baru, tidak hanya terpaku dengan buku teks sebagai media pembelajaran sejarah. Namun, peserta didik dapat mengakses dan mendapatkan informasi mengenai materi pelajaran sejarah seperti pendudukan jeang di Indonesia melalui video pembelajaran dari Gawai/telfon genggam peserta didik dan Internet karena berkenaan dengan era digital di masa yang semakin meningkat ini.

\section{DAFTAR PUSTAKA}

Abdullah, T dkk. Tanpa Tahun. Sejarah Pemikiran, Rekonstruksi, Persepsi 10: Memahami Kontroversi Sejarah Orde Baru. Jakarta: Masyarakat Sejarawan Indonesia.

Bungin, B. 2010. Penelitian Kualitatif. Putra Grafika

Collingwood, R.C. 2001. The Principles Of History . New York : Oxford University Press. Creswell, J. W. 2016. Research Design : Pendekatan Metode Kualitatif, Kuantitatif dan Campuran (Keempat). Pustaka Pelajar. 
Hafizh, A., \& Yefterson, R. B. (2019). Pengembangan Media Pembelajaran Berbasis Video Menggunakan Windows Movie Maker Dalam Pembelajaran Sejarah. Jurnal Halaqah, 1 (3), 224-245.

Hasan, S. Hamid. 2012. Pendidikan Sejarah Untuk Memperkuat Pendidikan Karakter. Dalam Jurnal Paramita. Vol. 22 No. 1. Bandung: Universitas Pendidikan Indonesia. Khairurrizqi, Aris Rahmansyah, T. H. (2015). Perancangan Graphical User Interface "Si Jambe" Sebagai Media Pembelajaran di Jambi. Jurnal Telkom University, 2(1), 171-178.

Kurniadi, M. D. (2018) Pengembangan Video Pembelajaran Sejarah Menggunakan Camtasia Studio 8 Materi Pendudukan Jepang Di Indonesia Untuk Siswa Kelas Xi Sma Xaverius 2 Kota Jambi. Skripsi. FKIP, Pendidikan Sejarah, Universitas Negeri Jambi.

Mulyono.2008. Manajemen Administrasi \& Organisasi Pendidikan. Yogyakarta: ArRuzz Media.

Sugiyono. 2014. Memahami Penelitian Kualitatif. Alfabeta

Susanto, H. 2014. Seputar Seputar Seputar Pembelajaran Sejarah Pembelajaran Sejarah (Isu, Gagasan dan Strategi (Isu, Gagasan dan Strategi (Isu, Gagasan dan Strategi Pembelajaran). Jakarta: Aswaja Pressindo

Sutirman. 2013. Media Dan Model-Model Pembelajaran Inovatif. Yogyakarta: Graha IImu.

Suwarni. 2016. Pembelajaran Sejarah Di Sekolah Menengah Atas (Studi Kasus Di SMA N 1 Prembun Dan SMA N 1 Pejagoan Kabupaten Kebumen). HIm: 124-136

Syahputra, M. A. D., \& Sariyatun, D. T. A. (2020). Pemanfaatan Situs Purbakala Candi Muaro Jambi Sebagai Objek Pembelajaran Sejarah Lokal Di Era Digital. Jurnal Pendidikan Sejarah Indonesia, 3(1), 77-87.

Zed, M. (2014). Metode Penelitian Kepustakaan (Pertama). Yayasan Obor Indonesia. 